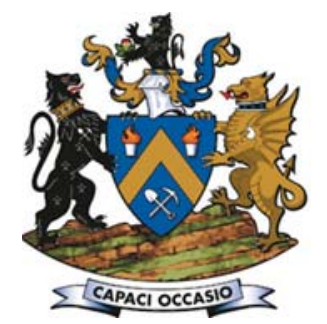

\title{
Purification of a dilute platinum group metals process stream using waste yeast biomass immobilized on plaster of Paris
}

\author{
by D. Oke*, S. Ndlovu*, and V. Sibanda*
}

\section{Synopsis}

The removal of platinum group metals (PGMs) from a dilute industrial process stream using a packed bed column of ethanol-treated waste yeast biomass immobilized on plaster of Paris (POP) was investigated. The study also included the removal of base metals and other trace elements in dilute solution. The effects of feed flow rate and bed depth on the breakthrough characteristics of the adsorption system were determined. The results showed that removal was favoured by lower flow rates and higher bed depths. An increase in the bed depth with a decrease in flow rate increased the volume of effluent that could be treated effectively before breakthrough. The breakthrough curves for most of the elements do not resemble an ideal breakthrough curve, due to the complexity of the solution. The normalized concentration for most of the metals in solution remained high, even in the early stages of treatment when the sorbent material was most pristine. Generally, the affinity of the sorbent for the elements considered followed the order $\mathrm{Pd}^{2+}>\mathrm{SO}_{4}{ }^{2-}$

$>\mathrm{Te}^{2+}>\mathrm{Pt}^{2+}>\mathrm{Ir}^{3+}>\mathrm{Ni}^{2+}>\mathrm{Cl}->. \mathrm{Ru}^{3+}>\mathrm{Se}^{2+}>\mathrm{Na}^{+}$. The data from the column studies was fitted to Adam-Bohart and Thomas models. The Adam-Bohart model showed a superior prediction of the experimental data. COD analysis of the effluent was also carried out at different time intervals. The measured COD decreased from $200 \mathrm{mg} / \mathrm{l}$ to less than $68 \mathrm{mg} / \mathrm{l}$ after 30 minutes, which corresponds to the removal efficiency of about $66 \%$.

\section{Keywords}

platinum group metals recovery, dilute process stream, biosorption, packed column, waste yeast biomass, immobilization.

\section{Introduction}

The recovery of metals from dilute platinum group metals (PGMs) process streams has a twofold advantage. Firstly, it minimizes contamination of the aquatic environment, and secondly, it recovers metals that have significant commercial value. Conventional methods for the removal of metals from wastewater have proven to be ineffective, especially in the case of very low metal concentrations. A satisfactory process would achieve the goal of metal recovery as well as wastewater purification at a relatively low cost, and without the generation of large amounts of residual solids. The search for new, effective and economical technologies for the removal of precious metals from waste streams has therefore shifted towards biosorption. Employing materials of biological origin allows existing knowledge to be applied to the development of technologies to treat metaland organic-containing solutions. These bio- sorbents possess metal-sequestering properties capable of quickly and efficiently decreasing the concentration of metals ions in dilute complex solution from parts per billion to parts per trillion (Wang and Cheng, 2006). For economic reasons, researchers have paid much attention to various byproducts from the fermentation industries because these are available in large quantities. One such waste from the food and beverage industry is brewery waste biomass, Saccharomyces cerevisiae. During fermentation, the yeast biomass increases three- to six-fold. However, this brewery waste material is largely used only as swine and ruminant feeds (Soares and Soares, 2012). The biosorbents can be treated by various chemical or physical processes to improve the effectiveness of their functional groups, thereby increasing the metal binding capacities.

The technical viability and biosorption capacity of the Saccharomyces cerevisiae waste biomass for the removal of PGMs from synthetic solution in a batch system has been investigated previously (Oke, Ndlovu, and Sibanda, 2014). However, for practical and large-scale operation, a packed column is preferred since a batch system is usually limited to the treatment of small quantities of wastewater. Free biomass has low mechanical strength and is not suitable for use in column applications (Rose and Townsley, 1986). Furthermore, high hydrostatic pressures are required to generate suitable flow rates in packed columns, and these high pressures can disintegrate the free biomass. These problems can be avoided by the use of immobilized biomass systems. In the biosorption processes for metal removal from wastes and dilute process streams, different immobilization

* University of the Witwatersrand, South Africa.

(C) The Southern African Institute of Mining and Metallurgy, 2017. ISSN 2225-6253. This paper was first presented at the Hydrometallurgy Conference 2016 'Sustainable Hydrometallurgical Extraction of Metals', 1-3 August 2016, Belmont Mount Nelson Hotel, Cape Town. 


\section{Purification of a dilute platinum group metals process stream using waste yeast biomass}

materials have been used. However, no published work is available on the treatment of dilute industrial PGM streams using Saccharomyces cerevisiae immobilized on plaster of Paris (POP). Therefore, the aim of this work was to use waste yeast immobilized on POP as a biosorbent for the purification of a dilute industrial PGM process stream. POP was chosen as a support material because of its cost-effectiveness compared to other support materials mentioned in the literature.

\section{Materials and methods}

\section{Biosorbent}

Spent waste yeast biomass was obtained from a fermenter at South African Breweries in Johannesburg. The yeast cells were initially washed with distilled water and the biosorbent separated by centrifugation. The biosorbent was air-dried and stored for further use.

\section{Chemical treatment of yeast cells}

Ethanol-treated yeast cells were prepared by suspending $30 \mathrm{~g}$ of cells in $100 \mathrm{ml}$ of $700 \mathrm{~g} / \mathrm{l}$ ethanol solution for 20 minutes (Goksungur, Uren, and Guvenc, 2002). After treatment, the yeast cells were collected by centrifugation, washed several times with distilled water, and air-dried.

\section{Dilute process solution}

The industrial dilute process solution used was collected at the process outlet stream of a South African PGM refinery.

\section{Plaster of Paris (POP)}

The POP used in biomass immobilization was purchased at a local hardware shop.

\section{Yeast immobilization on plaster of Paris}

Immobilization of the yeast biomass was carried out with POP as support material using the method reported by Ghosh, (1988). The ethanol-treated yeast was suspended in water and plaster was added to form a thick dough. The final concentration of yeast was $20 \%(\mathrm{w} / \mathrm{v})$. Beads (4.5-5.5 mm) were cast from the plaster dough and kept overnight at 26$28^{\circ} \mathrm{C}$. The beads were then washed under running tap water to remove any loosely adherent yeast and again kept overnight at $26-28^{\circ} \mathrm{C}$. The immobilization procedure as reported by Ghosh (1988) was slightly modified: radiation killing of the yeast cells was avoided (radiation killing is a form of heat treatment using ultraviolet light), and the yeast cells were used as-is after immobilization for purification of the PGMs effluent.

\section{Characterization the dilute industrial process stream}

The dilute industrial solution was characterized for total solids (TS), total dissolved solids (TDS), total suspended solids (TSS), pH, chloride, ammonia, sulphate, and salinity (conductivity). The PGM and base metals contents were analysed by inductively coupled plasma-mass spectrometry (ICP-MS) (Perkin Elmer Nexlon 300D). Table I gives the chemical composition of the PGM stream as received.

Chemical oxygen demand (COD) was determined with a Spectroquant Pharo 300 in accordance with the instructions of the manufacturer.

\section{Column experiments}

Column experiments were conducted in an acrylic glass tube of $25 \mathrm{~cm}$ inner diameter and $45 \mathrm{~cm}$ height packed with yeast immobilized on plaster of Paris. Glass beads were introduced at the top and the bottom of the packed column to prevent the adsorbent from floating. The dilute PGM process solution was conditioned to $\mathrm{pH} 3$ (the optimum $\mathrm{pH}$ for adsorption obtained in the batch experiments (Oke, Ndlovu, and Sibanda, 2014) using $0.1 \mathrm{M} \mathrm{NaOH}$ and $\mathrm{HCl}$ solutions. The solution, with known concentration of solutes, was pumped through the column in an upflow direction using a peristaltic pump (Watson Marlow 5045) with variable speed adjustment. The upflow movement was chosen because it minimizes clogging and unintentional filtration. Samples were collected from the column at regular intervals and analysed by ICP-MS (Perkin Elmer Nexlon 300D). Figure 1 is a schematic of the experimental set-up for the column study.

The experimental conditions chosen for investigating the sorption performance of POP yeast in a fixed- bed column were as follows: bed depth $6.5,8.5$, and $13 \mathrm{~cm}$; flow rate 0.9 , 1.3 , and $2.1 \mathrm{ml} / \mathrm{s}$. All experiments were carried out for 180

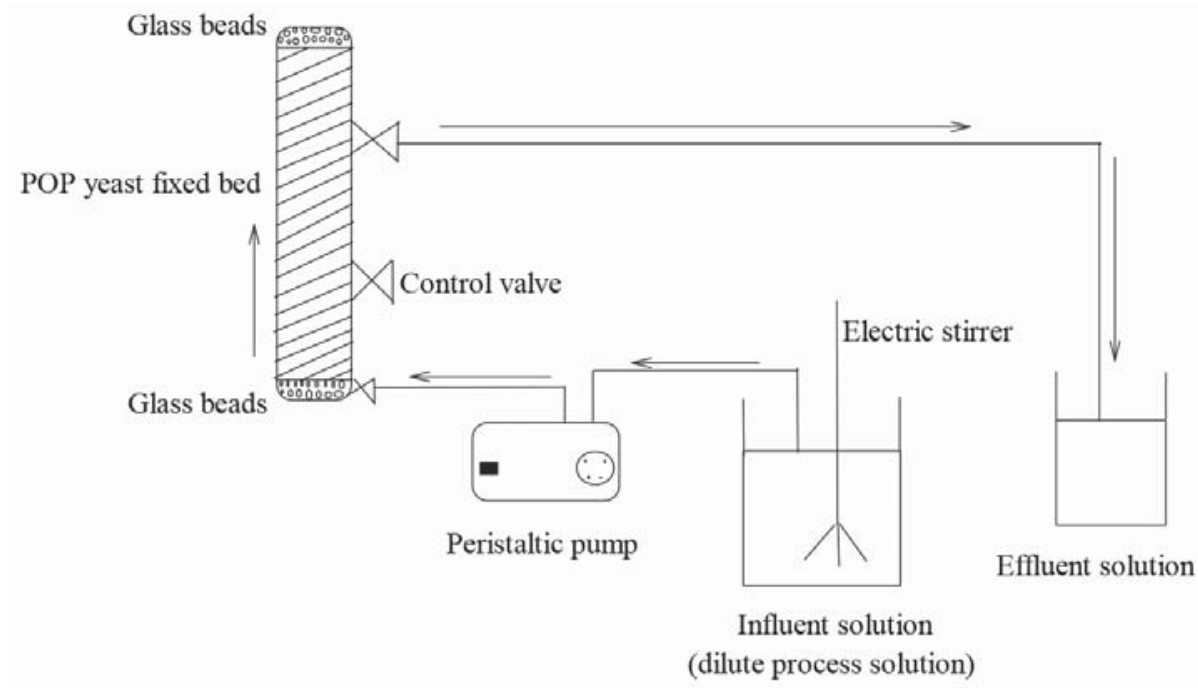




\section{Purification of a dilute platinum group metals process stream using waste yeast biomass}

minutes. The flow rates and bed depths were chosen based on information from the literature (Calero et al., 2009; Danny, Porter, and McKay, 2000). The pH and the time used were based on the information gathered from the batch studies (Oke, Ndlovu, and Sibanda, 2014).

\section{Control experiments}

Control experiments were performed with only the POP beads without yeast to ascertain the adsorption characteristics of POP itself (if any).

\section{Results and discussion}

\section{Characterization of dilute PGM solution}

Table I gives a summary of the physico-chemical characteristics of the PGMS effluent stream. Most of the values are above the permissible limit set by the US Environmental Protection Agency (USEPA, 2010) as well as the Department of Water Affairs and Forestry, South Africa (DWAF, 1996).

The high concentration of sulphate, sodium, and chloride ions causes the solution to have a very high ionic strength. The ionic strength and the pH strongly influence metal speciation and the type of metal ion complexes in industrial wastewater. The solubility of most metals decreases as the ionic strength of the medium increases. According to the

\begin{tabular}{|c|c|c|c|}
\hline \multicolumn{4}{|c|}{$\begin{array}{l}\text { Table I } \\
\text { Physico-chemical characterization of the dilute } \\
\text { PGMs solution }\end{array}$} \\
\hline Characteristic & $\begin{array}{l}\text { Measured } \\
\text { value }\end{array}$ & $\begin{array}{l}\text { USEPA } \\
\text { limits }\end{array}$ & $\begin{array}{l}\text { DWAF } \\
\text { guideline for } \\
\text { industrial } \\
\text { disposal }\end{array}$ \\
\hline $\mathrm{pH}$ & 1.8 & $\mathrm{n} / \mathrm{a}$ & $5-10$ \\
\hline Total conductivity (mS/m) & 12,644 & $\mathrm{n} / \mathrm{a}$ & $\mathrm{n} / \mathrm{a}$ \\
\hline Colour & Brown & $\mathrm{n} / \mathrm{a}$ & $\mathrm{n} / \mathrm{a}$ \\
\hline$\overline{\mathrm{COD}}(\mathrm{mg} / \mathrm{l})$ & 200 & 5 & $0-75$ \\
\hline TSS (mg/l) & 1080 & 4 & $0-25$ \\
\hline TDS (mg/l) & 220 & 50 & $\mathrm{n} / \mathrm{a}$ \\
\hline$\overline{\mathrm{TS}}(\mathrm{mg} / \mathrm{l})$ & 1300 & $\mathrm{n} / \mathrm{a}$ & $0-1600$ \\
\hline Chloride (mg/l) & 3497 & $\mathrm{n} / \mathrm{a}$ & $0-500$ \\
\hline Sulphate $\left(\mathrm{SO}_{4}\right)(\mathrm{mg} / \mathrm{l})$ & 10,947 & 5 & $0-500$ \\
\hline $\begin{array}{l}\mathrm{t}\left(\mathrm{NH}_{3}\right) \text { (total ammonia) } \\
(\mathrm{mg} / \mathrm{l})\end{array}$ & 79.1 & 0.01 & $\mathrm{n} / \mathrm{a}$ \\
\hline $\mathrm{Ag}(\mathrm{mg} / \mathrm{l})$ & 0.004 & $\mathrm{n} / \mathrm{a}$ & $\mathrm{n} / \mathrm{a}$ \\
\hline $\mathrm{Au}(\mathrm{mg} / \mathrm{l})$ & 0.015 & 0.005 & $\mathrm{n} / \mathrm{a}$ \\
\hline $\mathrm{Pd}(\mathrm{mg} / \mathrm{l})$ & 0.248 & 0.02 & $\mathrm{n} / \mathrm{a}$ \\
\hline $\mathrm{Pt}(\mathrm{mg} / \mathrm{l})$ & 1.88 & 0.1 & $\mathrm{n} / \mathrm{a}$ \\
\hline $\mathrm{Rh}(\mathrm{mg} / \mathrm{l})$ & 0.065 & 0.02 & $\mathrm{n} / \mathrm{a}$ \\
\hline $\operatorname{lr}(\mathrm{mg} / \mathrm{l})$ & 8.25 & 0.02 & $\mathrm{n} / \mathrm{a}$ \\
\hline $\mathrm{Ru}(\mathrm{mg} / \mathrm{l})$ & 0.937 & 0.1 & $\mathrm{n} / \mathrm{a}$ \\
\hline $\mathrm{Co}(\mathrm{mg} / \mathrm{l})$ & 0.026 & 0.005 & $n / a$ \\
\hline $\mathrm{Cu}(\mathrm{mg} / \mathrm{l})$ & 0.275 & 0.005 & 0.006 \\
\hline Zn (mg/l) & 0.077 & 0.0002 & 0.05 \\
\hline$\overline{\mathrm{Te}}(\mathrm{mg} / \mathrm{l})$ & 1.24 & 0.02 & $n / a$ \\
\hline Se (mg/l) & 416 & 0.01 & 0.05 \\
\hline $\mathrm{Fe}(\mathrm{mg} / \mathrm{l})$ & 1.17 & 0.005 & $0.0-10.0$ \\
\hline $\mathrm{Na}(\mathrm{mg} / \mathrm{l})$ & 45100 & 0.1 & $n / a$ \\
\hline $\mathrm{Ni}(\mathrm{mg} / \mathrm{l})$ & 2.08 & 0.005 & $\mathrm{n} / \mathrm{a}$ \\
\hline
\end{tabular}

DWAF guidelines (shown alongside the dilute process stream characteristics in the table), the wastewater is not suitable for re-use in industrial processes. The $\mathrm{pH}$, chloride, and sulphate levels are likely to lead to problems such as corrosion and scaling of process equipment.

\section{Chemical oxygen demand (COD)}

The chemical oxygen demand (COD) test is commonly used to indirectly measure the amount of organic compounds in water. During the adsorption process, the COD of the effluent was measured at different time intervals. The COD decreased from $200 \mathrm{mg} / \mathrm{l}$ to less than $68 \mathrm{mg} / \mathrm{l}$ after 30 minutes, which corresponds to a removal efficiency of about $66 \%$. Beyond this time, there was no significant change in the COD level.

\section{Column experiments}

Continuous-mode sorption studies play an important role in evaluating the technical feasibility of a treatment process for industrial application (Akar and Divriklioglu, 2010). This work focused on the removal of metal species with high concentrations or those species found to be above their discharge limit (in the case of base metals and the anions) or with concentrations above $0.1 \mathrm{mg} / \mathrm{l}$ in the case of PGMs. The species of interest include sulphates, chlorides, $\mathrm{Na}, \mathrm{Ni}, \mathrm{Se}$, $\mathrm{Ru}, \mathrm{Pd}, \mathrm{Pt}$, and Ir. For the test work, the dilute process stream was conditioned to $\mathrm{pH} 3$ (the optimum $\mathrm{pH}$ for PGM adsorption in the batch studies (Oke, Ndlovu, and Sibanda, 2014).

\section{Control experiments}

The results from the control experiments showed that the adsorption of the species of interest was due to the functional groups on the biomass, as reported by Oke, Ndlovu, and Sibanda, (2014), and not affected in any way by the POP.

\section{Effect of flow rate}

The effect of flow rate on the biosorption of the metals of interest was studied by varying the flow rate from 0.9 to 2.1 $\mathrm{ml} / \mathrm{s}$ while the bed height was held constant at $13 \mathrm{~cm}$. The breakthrough curves were constructed as $C / C_{0}$ (where $C$ is the effluent concentration at time $t$, and $C_{0}$ is the initial concentration of the influent stream) versus time, as presented in Figures 2-4. Breakthrough is considered to have occurred when there is a sharp increase in the outlet concentration. The breakthrough time is arbitrarily inferred to occur at $C / C_{0}=0.05$ according to Oliviera et al. (2011). However, the breakthrough in this study is based on the allowable discharge limits of various metal of interest as outlined by USEPA (2010), as well as by DWAF (1996), as given in Table II. In addition, saturation was assumed to have occurred when the effluent concentration was generally at $90-95 \%$ of the influent concentration (Oliviera et al., 2011). However, from examination of Figures $2-4$, it can be concluded that saturation of the bed, by the above definition, was not reached. In addition, the steepness of most of the graphs shows that frequent and accurate monitoring of the effluent quality is needed to ensure that a high concentration of the contaminant is not allowed to exit the column before the run is terminated (Benjamin and Lawler, 2013). The steepness of the breakthrough curve determines the extent to which the capacity of an adsorbent bed can be utilized.

Figures 2-4 show the breakthrough curves of some of the elements studied at different flow rates. The choice of 


\section{Purification of a dilute platinum group metals process stream using waste yeast biomass}

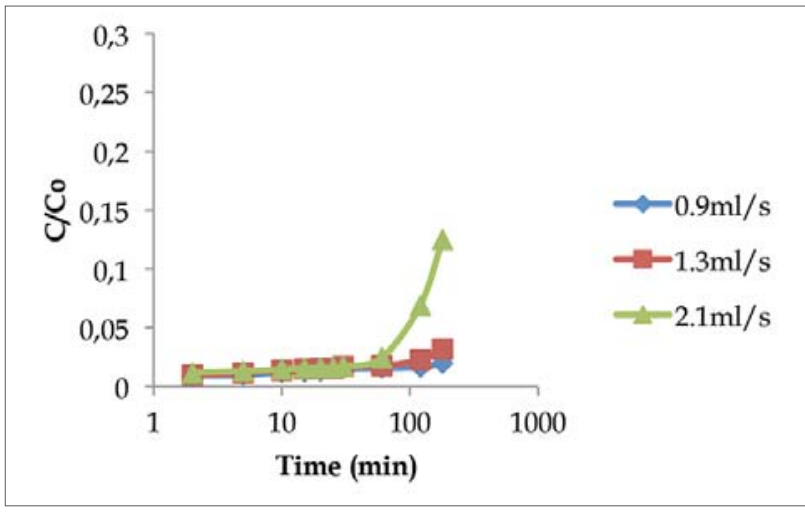

Figure 2-Breakthrough curves for palladium adsorption at different flow rates $\left(C_{o}=0.248 \mathrm{mg} / \mathrm{l}\right.$, bed height $\left.=13 \mathrm{~cm}, T=25^{\circ} \mathrm{C}\right)$

elements was not based on any criteria, but is intended as a representation of the whole study, as due to space limitations the breakthrough curves for all the elements studied cannot be included in this manuscript. Figure 2 shows the effect of flow rate on the adsorption of palladium at an inlet metal concentration of $0.248 \mathrm{mg} / \mathrm{l}$. The results show that if the maximum allowable limit for palladium is $0.02 \mathrm{mg} / \mathrm{l}$ (Table III), then the breakthrough time occurred at 180 minutes for a flow rate of $0.9 \mathrm{ml} / \mathrm{s}, 120$ minutes for $1.3 \mathrm{ml} / \mathrm{s}$, and 60 minutes for $2.1 \mathrm{ml} / \mathrm{s}$. For a sharp breakthrough to occur at the lower flow rates, and for the bed to be saturated with palladium ions, the adsorption time must be prolonged beyond 180 minutes. Since a longer breakthrough time implies better adsorption capacity, when operating at lower flow rates it would take much longer for the adsorbent to be completely saturated with the adsorbate. It can be inferred from Figure 2 that despite the very low concentration of palladium in the influent, the sorbent has high affinity for palladium.

Figure 3 shows the effect of solution flow rate on the adsorption of sulphate ions at an inlet concentration of 10 $947 \mathrm{mg} / \mathrm{l}$.The figure shows that as the flow rate increased, the breakthrough time decreased from 30 minutes to 10 minutes. In addition, despite the high concentration of sulphate ions in solution, saturation of the column could not be achieved, unlike other ions with high concentrations in solution such as $\mathrm{Se}^{2+}$, and $\mathrm{Na}^{+}$(data not shown). This may be explained by using the point of zero charge ( $\mathrm{pHzc}$ ) of the yeast. The pHzc of the yeast is 6.31; at pH values lower than this, the surface of the sorbent will be positively charged and will thus attract negatively charged ions. This may be the reason why sulphate ions and metals such as platinum and palladium, which form negative complexes such as chloroanionic complex in solution, were easily adsorbed from the solution regardless of their concentration.

Figure 4 shows the effect of solution flow rate on the adsorption of tellurium at an inlet concentration of $1.24 \mathrm{mg} / \mathrm{l}$. The results show that the breakthrough time decreased from 30 minutes to 10 minutes as the flow rate increased from 0.9 to $2.1 \mathrm{ml} / \mathrm{s}$. In addition, it can be seen that the allowable limit $(0.02 \mathrm{mg} / \mathrm{l})$ for tellurium was achievable only at a flow rate of $0.9 \mathrm{ml} / \mathrm{s}$.

Table II summarizes the breakthrough times at different flow rates for the different metals. The overall results show that as the flow rate increased, the breakthrough time decreased.

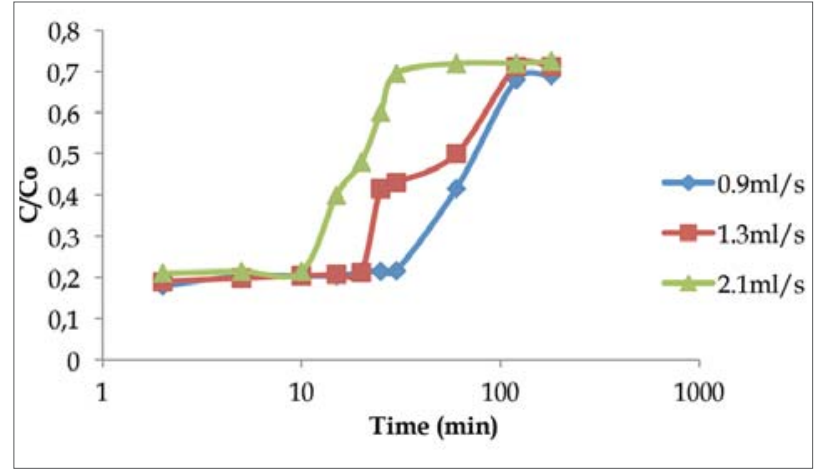

Figure 3-Breakthrough curve for sulphate adsorption at different flow rates $\left(C_{o}=10,947 \mathrm{mg} / \mathrm{l}\right.$, flow rate $\left.=0.9 \mathrm{ml} / \mathrm{s}, T=25^{\circ} \mathrm{C}\right)$

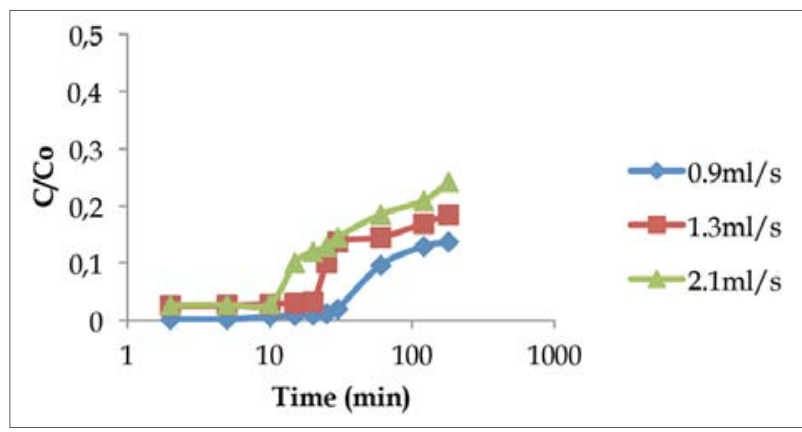

Figure 4-Breakthrough curve for tellurium adsorption at different flow rates $\left(C_{o}=1.24 \mathrm{mg} / \mathrm{l}\right.$, flow rate $\left.=0.9 \mathrm{ml} / \mathrm{s}, T=25^{\circ} \mathrm{C}\right)$

With increased flow rate, the bed utilization, as well as the bed adsorption capacity, will be reduced. This is due to insufficient residence time of the solute in the column, leading to insufficient diffusion of the solute into the pores of the adsorbent. The solute therefore leaves the column before equilibrium is established. These results are in agreement with findings in the literature for systems of biosorption in columns for different metals using different sorbent materials (Calero et al., 2009; Danny, Porter, and McKay, 2000; Khan, Bury, and Hogstrand, 2011). For most of the platinum group metals present in the solution under study, a prolonged residence time, typically more than 180 minutes, is required to reach column saturation, regardless of the flow rate used. The significant difference in breakthrough time for palladium compared with the other PGMs is due to the fact that the sorbent has high affinity for palladium, which is in agreement with the results obtained in the batch studies.

The experimental results indicate that a flow rate of 0.9 $\mathrm{ml} / \mathrm{s}$ produces a classic breakthrough curve to work with compared to the higher flow rates tested, since a longer breakthrough time indicates higher efficiency of the

\section{Table II \\ Breakthrough times (minutes) at different flow rates}

\begin{tabular}{|l|c|c|c|c|c|c|c|c|c|c|}
\hline Flow rate & $\mathbf{P t}$ & $\mathbf{P d}$ & $\mathbf{I r}$ & $\mathbf{R u}$ & $\mathbf{S e}$ & $\mathbf{T e}$ & $\mathbf{N i}$ & $\mathbf{N a}$ & $\mathbf{S O}_{4}$ & $\mathbf{C l}$ \\
\hline $0.9 \mathrm{ml} / \mathrm{s}$ & 25 & 180 & 25 & 10 & 10 & 30 & 25 & 5 & 30 & 25 \\
\hline $1.3 \mathrm{ml} / \mathrm{s}$ & 10 & 120 & 10 & 5 & 2 & 20 & 15 & 2 & 20 & 15 \\
\hline $2.1 \mathrm{ml} / \mathrm{s}$ & 5 & 60 & 5 & 2 & 2 & 10 & 10 & 2 & 10 & 5 \\
\hline
\end{tabular}




\section{Purification of a dilute platinum group metals process stream using waste yeast biomass}

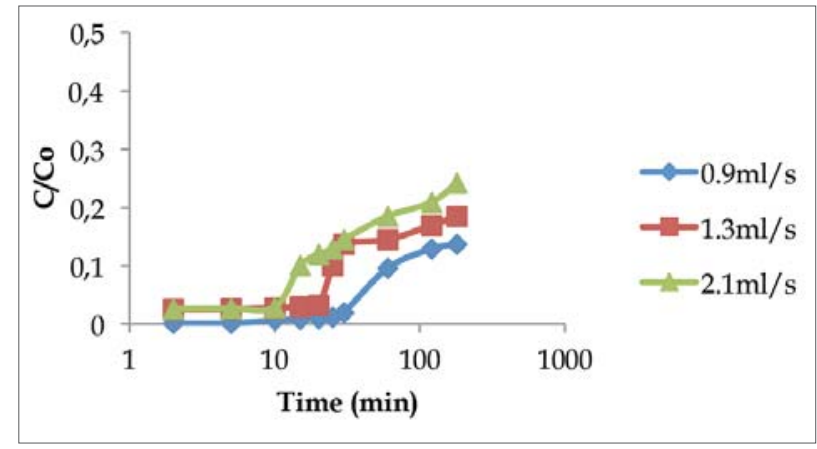

Figure 5-Breakthrough curve for palladium at different bed depth $\left(\boldsymbol{C}_{0}=\right.$ $0.248 \mathrm{mg} / \mathrm{l}$, flow rate $=0.9 \mathrm{ml} / \mathrm{s}, T=25^{\circ} \mathrm{C}$ )

adsorbent. Therefore, the subsequent experiments were carried out at a flow rate of $0.9 \mathrm{ml} / \mathrm{s}$.

\section{Effect of bed depth}

The retention of metal ions in a fixed-bed column depends, among other factors, on the quantity of solid sorbent used or on the bed depth of the column (Calero et al., 2009). The sorption performance of plaster of Paris-immobilized yeast was assessed using bed depths of $6.5 \mathrm{~cm}, 8.5 \mathrm{~cm}$, and $13 \mathrm{~cm}$ at flow rate of $0.9 \mathrm{ml} / \mathrm{s}$. Figure 5 shows the effect of bed depth on the sorption of palladium. As the bed height decreased from $13 \mathrm{~cm}$ to $6.5 \mathrm{~cm}$, the breakthrough time decreased from 180 minutes to 30 minutes. This is because at lower bed depth there are fewer binding sites, which are quickly taken up by the adsorbing ions.

Figure 6 shows the effect of bed depth on the sorption of sulphate ions. The results similarly show that the breakthrough time increased from 10 minutes to 30 minutes when the bed depth increased from $65 \mathrm{~mm}$ to $130 \mathrm{~mm}$.

Figure 7 shows the effect of bed depth on the sorption of tellurium. The breakthrough time increased from 10 minutes to 30 minutes as the bed depth increased from $6.5 \mathrm{~cm}$ to 13 $\mathrm{cm}$. The results demonstrate that the adsorbent has a high affinity for tellurium compared to platinum, ruthenium, and nickel, which were also present in lower concentration in the solution.

Table III summarizes the breakthrough times for different metals at different bed depths. Generally, the breakthrough time increased as the bed depth increased from $6.5 \mathrm{~cm}$ to 13 $\mathrm{cm}$. Similarly, the time necessary for saturation of the column is higher as the bed depth is increased; in some cases a

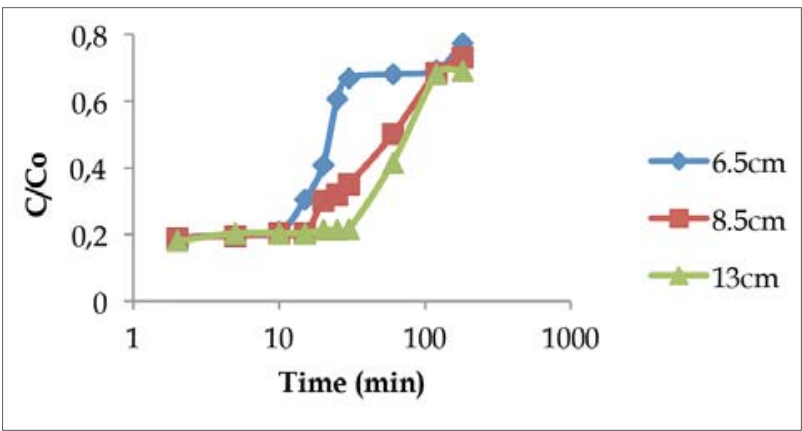

Figure 6-Breakthrough curve for sulphate adsorption at different bed depth $\left(C_{o}=10,947 \mathrm{mg} / \mathrm{l}\right.$, flow rate $\left.=0.9 \mathrm{ml} / \mathrm{s}, T=25^{\circ} \mathrm{C}\right)$

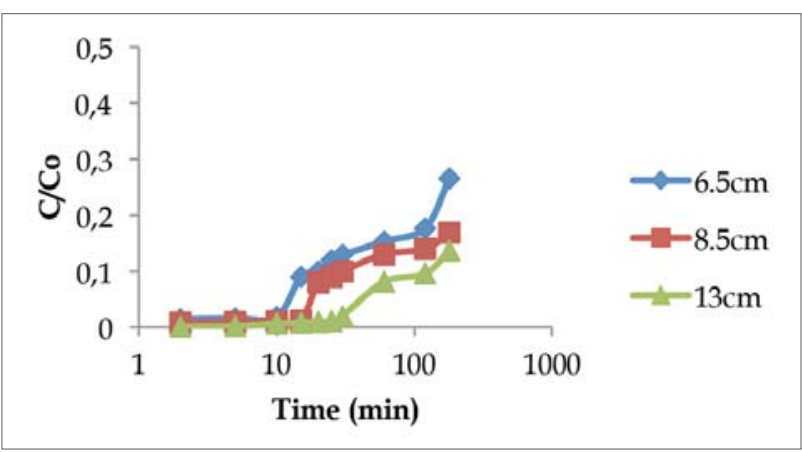

Figure 7-Breakthrough curves for tellurium adsorption at different bed depths $\left(C_{o}=1.24 \mathrm{mg} / \mathrm{l}\right.$, flow rate $\left.=0.9 \mathrm{ml} / \mathrm{s}, T=25^{\circ} \mathrm{C}\right)$

contact time longer than 180 minutes was necessary. Although an increase in bed depth increased the breakthrough time, a very deep bed is not practical for a single column; instead, multiple columns should be designed (Netpradit, Thiravetyan, and Towprayoon, 2004). This is because when the bed height (the adsorbent dosage) increases to a certain level, the adsorption density (the amount adsorbed per unit mass) decreases.

Based on the information in Tables II and III, it is evident from the breakthrough times $\left(t_{b}\right.$ values at $0.9 \mathrm{ml} / \mathrm{s}$ and 13 $\mathrm{cm}$ ) that the binding affinity for the PGMs in the solution under study on POP-immobilized yeast follows the order $\mathrm{Pd}^{2+}>\mathrm{Pt}^{2+}>\mathrm{Ir}^{3+}>\mathrm{Ru}^{3+}$, while the binding affinity for other elements in the solution follows the order $\mathrm{Te}^{2+}>\mathrm{SO}_{4}{ }^{2-}$ $>\mathrm{Ni}^{2+}>\mathrm{Se}^{2+}>\mathrm{Cl}->\mathrm{Na}^{+}$. Generally, the binding affinity for all the elements follows the order Pd2+> SO42$>\mathrm{Te}^{2+}>\mathrm{Pt}^{2+}>\mathrm{Ir}^{2+}>\mathrm{Ni}^{2+}>\mathrm{Cl}->\mathrm{Ru}^{2+}>\mathrm{Se}^{2+}>\mathrm{Na}^{+}$.

Table IV gives the allowable discharge limits of various elements (USEPA, 2010) and the metal concentration at breakthrough point (flow rate $0.9 \mathrm{ml} / \mathrm{s}$ and $13 \mathrm{~cm}$ bed depth). Most of the elements in the solution did not reach their allowable discharge limit even before breakthrough was achieved, except Pd and Te. Therefore a multiple column is recommended for practical purposes in treating effluents of this nature.

As the concentration of chloride was one of the highest among the contaminating anions, the chloride concentration was also monitored. The chloride concentration decreased in the early stage of treatment (at $0.9 \mathrm{ml} / \mathrm{s}$ and $13 \mathrm{~cm}$ bed depth), indicating that the column did adsorb chloride ions. Within 20 minutes, the chloride concentration had reached $2098 \mathrm{mg} / \mathrm{l}$, equivalent to $40 \%$ removal. It is therefore expected that the use of more columns will inevitably continue to decrease the concentration of anions and other elements in solution, but a decision must be made regarding how many columns would be economically feasible.

\section{Table III \\ Breakthrough times (minutes) at different bed depths}

\begin{tabular}{|l|c|c|c|c|c|c|c|c|c|c|}
\hline Flow rate & $\mathbf{P t}$ & $\mathbf{P d}$ & $\mathbf{I r}$ & $\mathbf{R u}$ & $\mathbf{S e}$ & $\mathbf{T e}$ & $\mathbf{N i}$ & $\mathbf{N a}$ & $\mathbf{S O}_{\mathbf{4}}$ & $\mathbf{C l}$ \\
\hline $6.5 \mathrm{~cm}$ & 10 & 30 & 10 & 2 & 2 & 10 & 10 & 2 & 10 & 10 \\
\hline $8.5 \mathrm{~cm}$ & 10 & 60 & 15 & 5 & 5 & 15 & 15 & 2 & 15 & 15 \\
\hline $13 \mathrm{~cm}$ & 25 & 180 & 25 & 10 & 10 & 30 & 25 & 5 & 30 & 25 \\
\hline
\end{tabular}




\section{Purification of a dilute platinum group metals process stream using waste yeast biomass}

\begin{tabular}{|l|c|c|c|c|c|c|c|c|c|c|}
\hline \multicolumn{1}{|l|}{ Table IV } \\
Discharge limits (USEPA, 2010) for tested elements in wastewater and breakthrough concentrations \\
\hline Component & $\mathbf{P t}$ & $\mathbf{P d}$ & $\mathrm{Se}$ & $\mathrm{Te}$ & $\mathbf{I r}$ & $\mathbf{R u}$ & $\mathbf{N a}$ & $\mathbf{S O}_{4}$ & $\mathbf{N i}$ & $\mathbf{C l}$ \\
\hline $\begin{array}{l}\text { Limit }(\mathrm{mg} / \mathrm{l}) \\
\begin{array}{l}\text { Concentration }\left(\mathrm{C}_{\mathrm{b}}\right) \text { at } \\
\text { breakthrough }(\mathrm{mg} / \mathrm{l})\end{array}\end{array}$ & 0.1 & 0.02 & 0.01 & 0.02 & 0.02 & 0.1 & 0.1 & 5 & 0.005 & 500 \\
\hline
\end{tabular}

Once the breakthrough time had been determined, the breakthrough capacity $Q_{B}$ (the column adsorption capacity at breakthrough point) of the adsorbent was calculated as (Goel et al., 2005):

$$
Q_{B}=\left(\frac{t_{b} Q_{w} C_{O}}{m}\right)
$$

where $t_{b}$ is the breakthrough time (minutes), $Q_{w}$ is the flow rate of the influent wastewater $(1 / \mathrm{min}), C_{o}$ is the inlet concentration $(\mathrm{mg} / \mathrm{l})$, and $m$ is the mass $(\mathrm{g})$ of the adsorbent. In addition, the volume of effluent treated $\left(V_{e f}\right)$ at breakthrough was calculated as:

$$
V_{e f}=Q t_{B}
$$

The results presented in Tables V and VI show that, the bed adsorption capacity $\left(Q_{b}\right)$ increases as the flow rate

\begin{tabular}{|c|c|c|c|}
\hline \multicolumn{4}{|c|}{$\begin{array}{l}\text { Table } \mathrm{V} \\
\text { Adsorption breakthrough data at different flow } \\
\text { rates }\end{array}$} \\
\hline Metal ion & $Q(\mathrm{ml} / \mathrm{s})$ & $Q_{b}(\mathrm{mg} / \mathrm{g})$ & $V_{\text {ef }}(\mathrm{ml})$ \\
\hline \multirow[t]{3}{*}{ Platinum } & 0.9 & 0.058 & 1350 \\
\hline & 1.3 & 0.034 & 780 \\
\hline & 2.1 & 0.027 & 630 \\
\hline \multirow[t]{3}{*}{ Palladium } & 0.9 & 0.056 & 9720 \\
\hline & 1.3 & 0.053 & 9360 \\
\hline & 2.1 & 0.043 & 7560 \\
\hline \multirow[t]{3}{*}{ Iridium } & 0.9 & 0.258 & 1350 \\
\hline & 1.3 & 0.149 & 780 \\
\hline & 2.1 & 0.12 & 630 \\
\hline \multirow[t]{3}{*}{ Ruthenium } & 0.9 & 0.012 & 540 \\
\hline & 1.3 & 0.008 & 390 \\
\hline & 2.1 & 0.005 & 252 \\
\hline \multirow[t]{3}{*}{ Nickel } & 0.9 & 0.065 & 1350 \\
\hline & 1.3 & 0.056 & 11790 \\
\hline & 2.1 & 0.060 & 1260 \\
\hline \multirow[t]{3}{*}{ Selenium } & 0.9 & 5.212 & 540 \\
\hline & 1.3 & 1.500 & 156 \\
\hline & 2.1 & 2.432 & 252 \\
\hline \multirow[t]{3}{*}{ Tellurium } & 0.9 & 0.046 & 1620 \\
\hline & 1.3 & 0.044 & 1560 \\
\hline & 2.1 & 0.036 & 1260 \\
\hline \multirow[t]{3}{*}{ Sodium } & 0.9 & 282.500 & 270 \\
\hline & 1.3 & 163.230 & 156 \\
\hline & 2.1 & 263.690 & 252 \\
\hline \multirow[t]{3}{*}{ Sulphate } & 0.9 & 411.460 & 1620 \\
\hline & 1.3 & 396.220 & 1560 \\
\hline & 2.1 & 320.020 & 1260 \\
\hline \multirow[t]{3}{*}{ Chloride } & 0.9 & 109.535 & 1350 \\
\hline & 1.3 & 94.930 & 1170 \\
\hline & 2.1 & 51.112 & 630 \\
\hline
\end{tabular}
decreases and the bed height increases. However, a slightly different trend was observed for selenium and sodium with regard to the value of $Q_{b}$ at different flow rates. The results indicated that the adsorption capacities $\left(Q_{b}\right)$ for selenium and sodium at $2.1 \mathrm{ml} / \mathrm{s}$ are higher than at $1.3 \mathrm{ml} / \mathrm{s}$. This may be a result of the low affinity of the adsorbent for these ions, which results in the same breakthrough value at the two flow rates.

The increase in the bed adsorption capacity $\left(Q_{b}\right)$ with increasing bed depth (Table VI) is due to the increase in the specific surface of the adsorbent, which supplies more fixation binding sites (Taty-Costodes et al., 2005). Furthermore, the results show that an increase in the bed depth with a decrease in flow rate increased the volume of effluent that could be treated effectively before breakthrough. Since industrial effluents contain more than one metal ion in solution, calculating the volume of effluent treated at breakthrough point will give an indication of the volume of solution that can be treated in order for each metal to reach its allowable limit, i.e. if the breakthrough time for each metal in the effluent is known, then the volume of effluent that can be treated effectively can be determined. However, a slightly different trend was observed for sodium with regard to the value of $Q_{b}$ at different bed depths. The adsorption capacity $\left(Q_{b}\right)$ for sodium is higher at $6.5 \mathrm{~cm}$ bed depth than at $8.5 \mathrm{~cm}$. This is a result of the close values of the breakthrough times at these bed depths.

\section{Evaluation of kinetic models}

The fundamental equations for a fixed-bed column depend on the mechanism responsible for the process (mass transfer from the liquid to the surface of the solid, diffusion and/or reaction on the surface of the solid), and include mass balances between the solid and the fluid and for the sorbed solute, rate of the process, etc. The equations derived to model the system with theoretical rigor are differential in nature and their solution usually requires complex numerical methods (Calero et al., 2009; Danny, Porter, and McKay, 2000). Because of this, various simple mathematical models such as Adam-Bohart (Bohart and Adams, 1920), Thomas (Thomas, 1944), Thomas, and Yoon and Nelson (Yoon and Nelson, 1984) have been developed to predict the dynamic behaviour of a column and allow some kinetic coefficients to be estimated. The Adam-Bohart and Thomas models were used in this study to analyse the behavior of the packed column.

The column data fitted better with the Adam-Bohart model than with the Thomas model for all the conditions tested. The results from the model indicated that the greater the bed height, the higher the adsorption capacity, No, of the adsorbent and the lower the mass transfer coefficient, KAB.

\section{Conclusions}

The removal of PGMs, as well as base metals and other trace elements, from a dilute industrial PGM solution was 


\section{Purification of a dilute platinum group metals process stream using waste yeast biomass}

\begin{tabular}{|c|c|c|c|}
\hline \multicolumn{4}{|c|}{$\begin{array}{l}\text { Adsorption breakthrough data at different bed } \\
\text { depths }\end{array}$} \\
\hline Metal ion & $Z(\mathrm{~cm})$ & $Q_{b}(\mathrm{mg} / \mathrm{g})$ & $V_{e f}(\mathrm{ml})$ \\
\hline \multirow[t]{3}{*}{ Platinum } & 6.5 & 0.037 & 540 \\
\hline & 8.5 & 0.045 & 540 \\
\hline & 13.0 & 0.058 & 1350 \\
\hline \multirow[t]{3}{*}{ Palladium } & 6.5 & 0.018 & 1620 \\
\hline & 8.5 & 0.029 & 3240 \\
\hline & 13.0 & 0.056 & 9720 \\
\hline \multirow[t]{3}{*}{ Iridium } & 6.5 & 0.198 & 540 \\
\hline & 8.5 & 0.245 & 810 \\
\hline & 13.0 & 0.258 & 1350 \\
\hline \multirow[t]{3}{*}{ Ruthenium } & 6.5 & 0.004 & 108 \\
\hline & 8.5 & 0.009 & 270 \\
\hline & 13.0 & 0.012 & 540 \\
\hline \multirow[t]{3}{*}{ Nickel } & 6.5 & 0.050 & 540 \\
\hline & 8.5 & 0.061 & 810 \\
\hline & 13.0 & 0.065 & 1350 \\
\hline \multirow[t]{3}{*}{ Selenium } & 6.5 & 2.000 & 108 \\
\hline & 8.5 & 4.120 & 270 \\
\hline & 13.0 & 5.212 & 540 \\
\hline \multirow[t]{3}{*}{ Tellurium } & 6.5 & 0.029 & 540 \\
\hline & 8.5 & 0.037 & 810 \\
\hline & 13.0 & 0.046 & 1620 \\
\hline \multirow[t]{3}{*}{ Sodium } & 6.5 & 217.350 & 108 \\
\hline & 8.5 & 178.650 & 108 \\
\hline & 13.0 & 282.530 & 270 \\
\hline \multirow[t]{3}{*}{ Sulphate } & 6.5 & 263.780 & 540 \\
\hline & 8.5 & 325.240 & 810 \\
\hline & 13.0 & 411.460 & 1620 \\
\hline \multirow[t]{3}{*}{ Chloride } & 6.5 & 84.265 & 540 \\
\hline & 8.5 & 103.898 & 810 \\
\hline & 13.0 & 109.535 & 1350 \\
\hline
\end{tabular}

investigated using Saccharomyces cerevisiae waste yeast immobilized on plaster of Paris support material in a packed column. Dynamic adsorption conditions such as bed height $(Z)$, and solution flow rate $(Q)$ were tested to establish their influence on the purification process. The packed bed column was found to perform better with lower influent rate and greater bed depth. In addition, it was found that for the bed to reach saturation for most of the metals, an adsorption time greater than 180 minutes was necessary. Successful selective binding and recovery of metal from the mixed metal solutions depended on the binding affinity of the metals, which followed the order $\mathrm{Pd}^{2+}>\mathrm{SO}_{4}{ }^{2}>\mathrm{Te}^{2+}>\mathrm{Pt}^{2+}>\mathrm{Ir}^{2+}>\mathrm{Ni}^{2+}>\mathrm{Cl}-$ $>\mathrm{Ru}^{3+}>\mathrm{Se}^{2+}>\mathrm{Na}^{+}$.

The study showed that if multiple fixed-bed columns are used, all the valuable metals can be recovered, and the concentration of other contaminants like sulphate, chloride, and sodium reduced to meet the Department of Water Affairs and Forestry (1996) guidelines for industrial water re-use. The purified stream could be used for dust suppression, firefighting, ash quenching, and irrigation etc. In light of continued population growth, ongoing contamination of both ground and surface waters, uneven distribution of water resources, and periodic droughts, consideration must be given to purifying industrial water. The recycling of the purified waste stream within the refinery would constitute a considerable saving in terms of water required from surrounding municipalities, which are already struggling to provide enough water.

\section{Acknowledgements}

The authors thank South African Breweries for the supply of the waste yeast used in this study, and the PGM refinery (which cannot be identified for confidentiality reasons) that provided the dilute process stream sample.

\section{References}

AKAR, T. and DivrikLIoglu, M. 2010. Biosorption application of modified fungal biomass for decolorization of reactive red 2 contaminated solutions: batch and dynamics flow mode studies. Bioresource Technology, vol. 101. pp. 7271-7277.

BENJAmin, M.M. and LAWLER, D.F. 2013. Water Quality Engineering: Physical/Chemical Treatment Processes. Wiley, Hoboken, New Jersey.

BонART, G.S. and ADAms, E.Q. 1920. Behavior of charcoal towards chlorine. Journal of Chemical Society, vol. 42. pp. 523-529.

Calero, M., Hernainz, F., Blazouez, G., Tenorio, G., and Martin-Lara, M.A. 2009. Study of $\mathrm{Cr}$ (III) biosorption in a fixed bed column. Journal of Hazardous Materials, vol. 171. pp. 886-893.

DAnNY, C.K., PoRTER, J.F., and McKAY, G. 2000. Optimized correlations for the fixed-bed adsorption of metal ions on bone char. Chemical Engineering Science, vol. 55. pp. 5819-5829.

Department of Water Affairs And Forestry. 1996. South African Water Quality Guidelines. 2nd edn. Volume 3: Industrial Use. Pretoria.

GHosh, G. 1988. Immobilization of baker's yeast using Plaster of Paris. Biotechnology Techniques, vol. 2, no. 3. pp. 217-219.

Goel, J., KRishna, K., ChiRA, R., and Vinod, K. 2005. Removal of lead (II) by adsorption using treated granular activated carbon and column studies. Journal of Hazardous Materials, vol. 125. pp. 211-220.

GoKSUnGUR, Y., UREn, S., and Guvenc, U. 2002. Biosorption of copper ions by caustic treated waste baker's yeast biomass, Turkey Journal of Biology, vol. 27. pp. 23-29.

Khan, F.R., Bury, N.R., and Hogstrand, C. 2011. Copper and zinc detoxification in Gammarux pulex. Journal of Experimental Biology, vol. 215. pp. 822-832.

MACK, C.L. 2005. Screening of technologies for the recovery of rhodium (III) metal ions from a precious metal refinery wastewater. MSc thesis. Rhodes University, South Africa.

Mack, C., Wilhelmi, B., Duncan, J.R., and BuRgess, J.E. 2007. Biosorption of precious metals. Biotechnology Advances, vol. 25, no. 3. pp. 264-271.

Mack, C., Wilhelmi, B., Duncan, J.R., and Burgess, J.E. 2008. A kinetic study of the recovery of platinum ions from an artificial aqueous solution by immobilized saccharomyces cerevisiae biomass. Minerals Engineering, vol. 21. pp. 31-37.

NetPradit, S., Thiravetyan, P., and TowPRAYoon, S. 2004. Evaluation of metal hydroxide sludge for reactive dye adsorption in a fixed-bed column system. Water Research, vol. 38. pp. 71-78.

OKE, D., NdLovu, S., and SibAndA, V. 2014. Removal of platinum group metals from dilute process streams: Identification of influential factors using DOE approach. Journal of Environmental Chemical Engineering, vol. 2. pp. 1061-1069.

Oliveira, R.C., JouAnnin, C., Guibal, E., and Garcia JR, O. (2011). Samarium (III) and praseodymium(III) biosorption on Sargassum sp: Batch study. Process Biochemistry, vol. 46, no. 3. pp. 736-744.

Ross, I. S. and TownsLey, C. C. 1986. The uptake of heavy metals by filamentous fungi. Immobilization of Ions by Biosorption. Eccles, $\mathrm{H}$. and Hunt, S. (eds). IRL Press, Chichester, UK.

SOARES, E.V. and SOARES, H.M.V.M. 2012. Bioremediation of industrial effluents containing heavy metals using brewing cells of Saccharomyces cerevisiae as a green technology; a review, Environmental Science and Pollution Research, vol. 19. pp. 1066-1083.

TAty-Costodes, V.C., Faudet, H., Porte, C., and Ho, Y.S. 2005. .Removal of lead (II) ions from synthetic and real effluents using immobilized Pinus sylvestris sawdust: adsorption on a fixed-bed column. Journal of Hazardous Materials, vol. 123. pp. 135-144.

THomAs, H.C. 1944. Heterogeneous ion exchange in a flowing system. Journal of American Chemical Society, vol. 66. pp. 1466-1664

United States Environmental Protection Agency. 2010. Permit Guidance. Research Triangle Park, North Carolina.

WANG, J. and CHEN, C. 2006. Biosorption of heavy metals by Saccharomyces cerevisiae: A review. Biotechnology Advances, vol. 24. pp. 427-421.

Yoon, Y.H. and Nelson, J.H. 1984. Application of gas adsorption kinetics. Part 1. A theoretical model for respirator cartridge service time. Journal of American Industrial Hygiene Association, vol. 45. pp. 509-516.. 